\title{
Contextual and task performance: role of employee engagement and organizational culture in hospitality industry
}

\author{
Bhawana Bhardwaj \\ School of Commerce and Business Management, \\ Central University of Himachal Pradesh, Dharamshala, India, and \\ Namrita Kalia \\ Department of Commerce and Business Management, DAV University, \\ Jalandhar, India
}

Employee

engagement

Received 22 August 2020 Revised 20 November 2020 Accepted 19 December 2020

\begin{abstract}
Purpose - Extensive work related to examining predictors and determinants of employee engagement and job performance have been conducted in past studies. A dearth of studies relating organizational culture and employee engagement with contextual and task performance in the hospitality industry necessitated the present study. This study aims to examine variability in the task and contextual performance owing to employee engagement and organizational culture.

Design/methodology/approach - The study has been conducted in four districts of Himachal Pradesh using a multistage sampling technique. A total of 360 hotel employees were involved in collecting their responses through a structured questionnaire.

Findings - The results of multiple regression showed that vigor, dedication and absorption variables of employee engagement contribute toward contextual performance. Vigor and absorption affect the task performance of employees. In the case of contextual performance vigor shows maximum contribution followed by absorption and dedication whereas for task performance, the maximum contribution is exhibited by absorption followed by vigor. Organizational culture sub-variables of experimentation, autonomy and trust came out to be major predictors, which help to improve contextual and task performance of employees.

Practical implications - The study suggests that psychological ownership, along with trust toward top management can create an enriched work culture, which influenced both the contextual and task performance of employees. The findings of the study can be practically used by government and private organizations for improving workforce performance in the hospitality industry. Future research can be conducted based on the findings of the study.

Originality/value - The study provides insight on how and to what extent cultural and employee engagement variables can affect employee's contextual and task performance. The present study adds value to the existing literature and investigates the role of culture and employee engagement in enhancing task and contextual job performance. Managers and policymakers can use the findings of the study to improve organizational culture, employee engagement and performance of the employees in the hospitality sector. The study opens avenues for future studies.
\end{abstract}

Keywords Employee engagement, Hospitality industry, Organizational culture, Job performance Paper type Research paper

(C) Bhawana Bhardwaj and Namrita Kalia. Published in Vilakshan - XIMB Journal of Management. Published by Emerald Publishing Limited. This article is published under the Creative Commons Attribution (CC BY 4.0) licence. Anyone may reproduce, distribute, translate and create derivative works of this article (for both commercial and non-commercial purposes), subject to full attribution to the original publication and authors. The full terms of this licence maybe seen at http://creativecommons.org/licences/by/4.0/legalcode

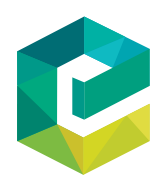

Vilakshan - XIMB Journal of Management Vol. 18 No. 2, 2021 pp. $187-201$ Emerald Publishing Limited 0973-1954 DOI 10.1108/XJM-08-2020-0089 
$\mathrm{XJM}$

18,2

188

\section{Introduction}

The hospitality industry is a major service industry in India accounting for more than a third of the total global services trade. It is a major source of foreign capital for India. The word hospitality is derived from the Latin word hospice, the term for a medieval house of rest for travelers and pilgrims. The hospitality industry deals with providing different lodging facilities and their interconnected services such as food, drinks and other related services. Hospitality comprises broadly of two different services, the first deals with providing provisions of overnight accommodation for the tourist who are staying away from their native places or homes and second, services related to sustenance of people eating away from home (Hartline and Jones, 1996). This industry helps tourists feel at home and have all their basic needs fulfilled even if they are away from their native place of stay.

The hilly state of Himachal Pradesh anciently called as "Dev Bhumi" (The land of Gods) has a rich cultural and geographical heritage. It is the northern state of the country and is one among the major tourist destinations. Being a tourist destination, the hospitality industry has a great scope in this state. As tourists are the major source of revenue for the state, therefore it is a necessity that they be provided with the best hospitality experience. Undoubtedly, the satisfaction of customers largely depends on the services of employees. For providing tourists best of experience and pleasant memories, it is important that the employees working in the hotels are taken care off. Hotels are not only a source of earning a livelihood for the employees but it also helps them develop their own identity. Every hotel is facing tough competition and is in the race of increasing its revenue. For its growth, it is very important that the organization continuously tries to identify areas of improvement and work for the development of its workforce; as this is a kind of service industry in which every employee working in the hotel in one way or the other is required to deal with the customers.

The employees in this industry although not a homogenous group, still share a number of common characteristics in terms of conditions and timings of work. Most of the time employees have to live in the premises of the hotel itself. Salary given to them is fairly low and they are expected to work overtime without due compensation, due to which employees are leaving this industry and turnover is fairly high (Maroudas et al., 2008). Therefore, finding out ways for improving employee's performance can play a major role in revenue generation for the hotels.

Being a service industry the success of a hotel is largely dependent on customer satisfaction. Contextual and task performance of employees plays a critical role in keeping customers happy. Although different factors promote the job performance of employees in the organization but organizational culture and employee engagement are two such variables that cover the individual and organizational context of performance. As the culture in which employees work instills in them the requisite believes and values, therefore, it is important to study what role does organization culture has on the performance of employees. Along with organizational culture, the study also tries to examine the influence of employee engagement specifically on contextual and task performance of hotel employees.

Past studies have lacked in understanding the role of these two variables on task performance and contextual performance. Therefore, the present study has been undertaken with the objective to assess the role of employee engagement variables in contextual and task job performance of hotel employees, to explore the role of organizational culture variables in influencing the contextual performance and to assess the influence of organizational culture variables on task performance of hotel employees. The outcome of this research will help the hospitality industry to gain useful insights into what are the 
factors that can promote the performance of their employees and how they can develop an engaged workforce through enhancing different components of organizational culture.

\section{Review of literature}

The construct of job performance

Job performance is one among the variables of organizational behavior, which have been studied widely and frequently by researchers all over the world (Bommer et al., 1995). The measurement of job performance can also be divided into job results, job behavior and personality traits (Robbins, 2005). It also refers to employees' performance in customer service. The performance of an employee can be categorized into in-role behavior called task performance and extra-role behavior or contextual performance (Goodman and Svyantek, 1999). Role expectations are mental constructs and expectations for a given work and may differ across other members of the role set (Conway, 1999). According to Motowidlo and Van Scotter (1994), task performance refers to those outcomes and behaviors that accomplish the objectives of the organization. Task performance may vary between jobs within the same organization (Behrman and Perreault, 1982). It is the behavior, which employees show instead of the monetary benefits they receive. Knowledge, skills and abilities, which vary with task proficiency are important characteristics for accomplishing task behaviors. Contextual performance is those minor roles, which are common and support the environment in which task performance takes place. Contextual performance depends on employee's predispositions and volition. Behaviors such as volunteering, helping, persisting predict volitional and predisposition, which includes person-organization fit (Borman and Motowidlo, 1993; Motowidlo and Van Scotter, 1994; Borman et al., 1995). Christen et al. (2006) noted that job performance increased with both effort and ability. Previous research suggests that among the various variables influencing job performance; employee engagement and organizational culture play an important role (Carrell and Elbert, 1974; Kónya et al., 2016; Marcus and Gopinath, 2017; Kalia and Bhardwaj, 2019).

\section{Factors influencing job performance}

Past research indicates that employees in the hospitality sector come across various problems such as job insecurity, lack of proper training; inadequate infrastructure facilities and high job transfer speed (Zhang and Wu, 2004; Sadiqe, 2014). Growing number of hospitality organizations are very much committed to provide their employees a positive experience to enhance their job performance (Hughes and Rog, 2008). Although there are various factors, which affect job performance such as leadership, creativity, personality, work environment (Bakker et al., 2012; Chughtai and Buckley, 2011; Buil et al., 2019), but employee engagement and organizational culture are the one's which are gaining utmost attention in today's changing scenario (Marcus and Gopinath, 2017; Prasongthan and Suveatwatanakul, 2017; Buil et al., 2019; Prihantari and Astika, 2019). However, there is a dearth of studies on the role of organizational culture and employee engagement in the hospitality section, therefore, the present study has been conducted. There are few studies, which have been reviewed to understand the role of these two variables with job performance and are as follows.

\section{Employee engagement and job performance}

The term "engagement" drives its being from role theory. Erving Goffman (1961) stated that it is a "spontaneous involvement in the role" and a "visible investment of attention and muscular effort." It was subsequently defined by different researchers (Kahn, 1990; Schaufeli et al., 2002; Conway, 1999), who characterized it by vigor, (which involves putting 
elevated levels of energy and mental resilience at work); dedication (being highly involved in work and experiencing enthusiasm, a sense of significance and challenge); and absorption, (being completely concentrated and engrossed in one's job).

It has been established that employee engagement improves job performance (Tensay and Singh, 2020). A high level of engagement among employees leads to a positive evaluation of task and contextual performance of employees (Bakker et al., 2007). Zainol et al. (2016), in their study on the hotel industry in Malaysia, found that effective and good employee engagement programs contributed to an increase in commitment, motivation and morale, which ultimately improves the performance of employees. A research on the Thai hotel industry by Prasongthan and Suveatwatanakul (2017), suggested that perceived organizational support and optimism demonstrate powerful influences on job performance through higher employee engagement. The primary results of this study revealed that there is a positive relationship between job performance and employee engagement. Engaged employees:

[...] work with greater intensity on their tasks for longer periods of time, they pay more attention to and are more focused on responsibilities, and they are more emotionally connected to the tasks that constitute their role (Rich et al., 2010).

Therefore, it is more likely that they will positively respond to customer requests and display better job performance.

A study conducted in Lebanon indicated a positive relationship between employee engagement and job performance. Engaged employees are considered to do their job well, have perseverance and take mentally and physically active roles to do the assigned work (Ismail et al., 2019). Existing conservation of resource theory proposes that employee engagement causes higher job performance by eliciting positive emotions that improve motivation to undertake job tasks and responsibilities (Parker and Griffin, 2011).

However, certain studies conducted on hospitality employees showed a partial effect of employee engagement on job performance (Buil et al., 2019) but most of the studies suggest that work engagement positively relates to employee performance (Bakker et al., 2012; Halbesleben and Wheeler, 2008; Buil et al., 2019). Thus, on the basis of the above discussion, the following hypothesis is proposed:

H1a. Employee engagement dimensions improve contextual performance of hotel employees.

H1b. Different sub-variables of employee engagement affect the task performance of hotel employees.

\section{Organizational culture and job performance}

The concept of organizational culture is rooted in the work of Pettigrew (1979) as "the system of personal and collectively accepted meanings of work, operating for a given group at a given period of time." Organizational culture is also referred to as collective programming of the mind, which differentiates the members of one organization from another organization. This comprises "beliefs, values, practices and shared expectations held by members of an organization” (Hofstede, 1989; Greenberg and Baron, 2003; Pratiwi et al., 2019; De Romario et al., 2019). It is a pattern or basic assumption shared by a group when solving problems of external adaptation and internal integration, which have succeeded and are considered 
legitimate to be taught to new members as an appropriate way of accepting, thinking and feeling related to this (Sukayana and Putri, 2019; Widiani et al., 2019).

According to Pareek (1994), organization culture consists of different components, which are as follows: openness; it is the freedom to communicate, share and interact openly without hesitation, receiving feedback from customers and freely providing ideas and suggestions to other employees. Employees who rated high on the level of openness were more open to a new learning experience, resulting in higher performance (Jena et al., 2018). Confrontation involves boldly facing the problems and challenges that one comes across and not escaping from them (Pareek, 1994). Authenticity is another important component of organizational culture. According to Subrahmanian (2012), it refers to the congruence between what one feels and says. Trust in the management and support of employee well-being at work (commitment, job satisfaction and work-life balance satisfaction) among workers is also important (Baptiste, 2008).

Openness, authoritative, affiliative and democratic leadership, trusting, empowering and extrinsic rewards, flexible work arrangements and supportive work culture, all promoted the job performance of employees (Bing and Lounsbury, 2000; Singh, 2010). A study done by Rashid et al. (2003) indicated that employees tend to give much value to continuous support and encouragement from higher management. Proactive employees help develop an environment of energy and enthusiasm around them in the organization. Taking initiative, preplanning and taking preventive action, using and encouraging innovative approaches to solve problems (Pareek, 1994). Development of new products, methods and procedures form an integral part of an effective organizational culture (Subrahmanian, 2012). According to Christen et al. (2006), job autonomy and quality of supervisory feedback positively affect work effort. Effort and ability contributed toward the overall job performance of the employees. Openness, trust and experimentation, apart from taking care of hygiene factors, improve job performance, thereby helping the organization gain an upper edge over others (Singh, 2010; Hofhuis et al., 2016).

Strong organizational culture produces better short-term performance (Gordon and DiTomaso, 1992). Robbins (2005), in a study on organizational culture, suggests that employees in companies whose culture is stronger are more committed to their company than employees in companies whose culture is weak. Firms with a strong culture continuously use their recruitment efforts and socialization practices to enhance employee commitment, which, in turn, enhances the job performance of employees. A strong organizational culture will help organizations provide certainty for their members and also enable them to develop along with organizational development (Prihantari and Astika, 2019). Previous studies have revealed that organizational culture influences and enhances the job performance of employees (Fauzi et al., 2016; Kim and Chang, 2019).

Thus, we propose that:

H2a. Different dimensions of organizational culture improves the contextual performance of employees.

$H 2 b$. Organizational culture dimensions affects the task performance of employees.

\section{Research methodology}

Sample for the study

The hilly state of Himachal Pradesh is an attractive tourist destination. According to the statistics of Department of tourism report (2019) Govt. of Himachal Pradesh, it attracted almost $4.57 \%$ domestic and $7.38 \%$ of international tourists in 2019 . As per the Department 
of Tourism, Govt. of Himachal Pradesh the state consists of 2,189 registered hotels. The sample from the state was collected using multistage sampling. In the first stage, 4 districts based upon the highest, middle and lowest number of hotels, namely, Bilaspur (15 hotels), Chamba (137 hotels), Kullu (578 hotels) and Kangra (301 hotels) were selected. These districts cover nearly $67 \%$ of the hotel population of the state and adequate to represent the hospitality sector of Himachal Pradesh.

In the second stage, hotels registered under the Department of Tourism, Govt. of Himachal Pradesh in these districts were arranged in alphabetical order and through systematic sampling, every 15th hotel from these districts was selected for the survey. As the state mostly possesses small and medium-sized budget hotels. Therefore, in the next stage, three or four frontline employees from each hotel were chosen for the survey through convenience sampling. The researcher contacted the general manager of each hotel, who helped the researcher to have one to one interaction with the employees so that purpose of the study could be well-explained to them. A total of 400 employees were contacted, however 360 frontline employees responded and participated in the study. A structured questionnaire was used to collect data from hotel employees. Employees were given the questionnaire and anonymity of their responses was assured. Participants returned their questionnaire in a closed response packet, which was collected in person by the researcher.

\section{Research tools}

A structured questionnaire consisting of three sections and comprising statements related to job performance, employee engagement and organizational culture was used for data collection. The first section measured the job performance of employees and consisted of two constructs measuring contextual and task performance of employees. The scale was based on the work of Goodman and Svyantek (1999). The scale had 7 statements for contextual performance and 9 statements for task performance, comprising a total of 16 statements. The subjects responded to a four-point Likert-type scale for all items in the questionnaire. These measures were anchored at highly valued, fairly high value, fairly low value and very low value that is $4,3,2$ and 1 , respectively.

The second section on employee engagement was based on research done by Schaufeli and Bakker (2003). The scale consisted of 17 statements about how one feels at work. It was rated on a seven-point scale, from 0 to 6 where 0 indicated never to 6 indicated always. The scale yielded scores on three areas of employee engagement, namely, vigor, dedication and absorption. Six statements represented vigor, six statements measure dedication and five statements examined absorption of the various parameters of employee engagement. The third section on organizational culture was based on Pareek's (1994) scale. It consisted of eight dimensions - openness, confrontation, trust, authenticity, pro-action, autonomy, collaboration and experimentation. This was rated on a four-point scale, (highly valued, fairly high value, fairly low value and very low value that is $4,3,2$ and 1, respectively). Each dimension consisted of five statements, and hence, it had a total of 40 items.

\section{Analysis and results}

To collect responses of the respondents a total of 160 hotels from the state were selected through multistage random sampling technique. Three or four frontline employees from every hotel were chosen for the survey. A total of 400 employees were contacted, however 360 frontline employees participated in the study. Out of 360 duly filled questionnaires, $77 \%$ were men and $45 \%$ of employees had completed their undergraduate level of education. The responses were coded and tabulated to analyze the data. The reliability of the scale was measured using Cronbach's $\alpha$. Each of the multi-scale items was found to be reliable with an 
$\alpha$ coefficient of 0.830 for employee engagement, 0.759 for organizational culture and 0.852 for job performance, all tested at the 0.95 level of significance.

\section{Role of employee engagement variables in contextual and task performance of hotel employees}

The regression analysis of employee engagement predictors for job performance is given in Table1. It revealed moderate to high contribution of employee engagement dimensions, namely, vigor, dedication and absorption, toward different dimensions of job performance.

Employee engagement showed $35.7 \%\left(R^{2}=0.357\right)$ variance in contextual performance and $45.2 \%\left(R^{2}=0.452\right)$ variance in task performance. This showed that employee engagement had a greater impact on task performance as compared to contextual performance.

The B-values further demonstrated that a $1 \%$ change in vigor was expected to produce a $25.6 \%(t=6.226, p<0.05)$ change in contextual performance and a $21.1 \%(t=6.184, p<$ $0.05)$ change in task performance. An increase of $1 \%$ in dedication increased contextual performance by $12.7 \%(t=2.986, p<0.05)$. However, dedication did not significantly affect the task performance of employees. The beta values further suggested a change of $19.6 \%$ $(t=3.499, p<0.05)$ in contextual performance and a $32.2 \%(t=6.892, p<0.05)$ change in task performance because of a $1 \%$ change in absorption. Thus, on the basis of the above findings, $\mathrm{HI} a$ is accepted and it can be inferred that all three employee engagement dimensions i.e. vigor, dedication and absorption play a role in influencing the contextual performance of hotel employees. However, $\mathrm{H} 1 b$ is partially accepted as only vigor and absorption significantly affect task performance. The engagement of employees tends to show improvements in job-related behaviors, which directly affects individual and organizational goals. The level of enthusiasm and dedication exhibited by the employees more affected the ways they perform their work roles rather than their psychological environment of work.

The above table reveals that all the three sub-variables of employee engagement that is vigor, dedication and absorption significantly influence contextual performance in which vigor shows maximum contribution followed by absorption and dedication. The employees were resilient mentally and were ready to work for long hours, which boosted their level of contextual performance. The perseverance of employees enabled them to create an environment of enhanced performance. Their energetic attitude and motivation for working even in odd hours helped increase their contextual performance.

If we talk about task performance it is affected significantly by vigor and absorption and absorption level has a greater effect on it. Employees felt a high level of belongingness with

\begin{tabular}{|c|c|c|c|c|}
\hline \multirow{3}{*}{$\begin{array}{l}\text { Employee engagement } \\
\text { dimensions }\end{array}$} & \multicolumn{4}{|c|}{ Job performance dimensions } \\
\hline & \multicolumn{2}{|c|}{ Contextual performance } & \multicolumn{2}{|c|}{ Task performance } \\
\hline & B-value & $t$-value & B-value & $t$-value \\
\hline Vigor & 0.256 & $6.226^{*}$ & 0.211 & $6.184^{*}$ \\
\hline Dedication & 0.127 & $2.986^{*}$ & 0.060 & 1.686 \\
\hline Absorption & 0.196 & $3.499 *$ & 0.322 & $6.892^{*}$ \\
\hline & 0.357 & & 0.452 & \\
\hline$F$-value & $63.903^{*}$ & & $95.214^{*}$ & \\
\hline
\end{tabular}

Notes: $* p<0.05$. Contextual performance $=3.310+0.256$ Vigor +0.127 Dedication +0.196 Absorption. Task performance $=3.462+0.211$ Vigor +0.322 Absorption

Table 1. Regression for employee engagement predictors for job performance 
$\mathrm{XJM}$

18,2

194

the organization. They said they did not come to know how quickly their time while in work shift passed away. They were happy working intensely at the hotel and it was difficult to distract them from their work. This showed their high absorption level while at work. The sense of belongingness and the engrossed attitude of employees make them perform well in their job roles and duties. The happiness, which the employee feels at work makes him more tasks efficient as compared to the parameter of vigor and dedication. Thus, among the three sub-variables absorption played a significant role in affecting the task performance of hotel employees.

\section{Role of organizational culture in contextual and task performance of hotel employee}

The values of multiple regressions for different dimensions of organizational culture and job performance are given in Table 2. This table shows a moderate contribution of organizational culture dimensions toward job performance of employees, estimated at $28.7 \%\left(R^{2}=0.287\right)$ variance in task performance and $31.2 \%\left(R^{2}=0.312\right)$ variance in contextual performance. This means that organizational culture can bring more change in the contextual performance of employees as compared to task performance. As contextual performance is the measurement of the environment at work, it is more influenced with the values and belief system prevalent in the organization.

The B-values suggested that a 1\% change in autonomy produced a significant $15.8 \%(t=$ $3.131, p<0.05)$ change in contextual performance, and a $29.8 \%(t=6.772, p<0.05)$ change in task performance. A $1 \%$ change in experimentation significantly changed contextual performance by $70.6 \%(t=8.645, p<0.05)$ and task performance by $57.6 \%(t=8.053, p<$ 0.05). A $1 \%$ change in trust was expected to produce a significant $17.8 \%(t=2.393, p<0.05)$ change in contextual performance and $12.4 \%(t=1.986, p<0.05)$ change in task performance. Thus, $H 2 a$ and $H 2 b$ are partially accepted as all the variables of organizational culture do not contribute to contextual and task performance. A culture of trust, autonomy and experimentation promotes the job performance of employees, whereas openness, confrontation, pro-action does not influence job performance of hotel employees.

The employees working in this industry are given the freedom to respond to situations in their own way. The supervisors and management of the hotels trust their employees. They

\begin{tabular}{|c|c|c|c|c|}
\hline \multirow[b]{3}{*}{ Organizational culture dimensions } & \multicolumn{4}{|c|}{ Job performance dimensions } \\
\hline & \multicolumn{2}{|c|}{ Contextual performance } & \multicolumn{2}{|c|}{ Task performance } \\
\hline & B-value & $t$-value & B-value & $t$-value \\
\hline Openness & 0.108 & 1.132 & 0.069 & 0.828 \\
\hline Confrontation & 0.004 & 0.053 & 0.076 & 1.099 \\
\hline Trust & 0.178 & $2.393^{*}$ & 0.124 & $1.986^{*}$ \\
\hline Authenticity & 0.070 & 1.119 & 0.008 & 0.139 \\
\hline Pro-action & 0.052 & 0.642 & 0.014 & 0.202 \\
\hline Autonomy & 0.158 & $3.131 *$ & 0.298 & $6.772^{*}$ \\
\hline Collaboration & -0.002 & -0.029 & -0.041 & -0.573 \\
\hline Experimentation & 0.706 & $8.645^{*}$ & 0.576 & $8.053 *$ \\
\hline$R^{2}$ & \multicolumn{2}{|c|}{0.287} & \multicolumn{2}{|c|}{0.312} \\
\hline$F$-value & \multicolumn{2}{|c|}{$13.248^{*}$} & \multicolumn{2}{|c|}{$16.730^{*}$} \\
\hline
\end{tabular}

Table 2.

Regression for organizational culture predictors for job performance

Notes: $* p<0.05$. Contextual performance $=2.055+0.158$ Autonomy +0.706 Experimentation +0.178 Trust. Task performance $=2.759+0.298$ Autonomy +0.576 Experimentation +0.124 Trust 
have full confidence and they support the on-the-spot decisions taken by their employees. There were instances, which the employees quoted in which management went out of the way to help them in financial and moral crisis. This not only developed a trust for the management but also boosted both their contextual and task performance. Second, subvariable of autonomy significantly influenced job performance of hotel employees. In many hotels, employees worked in self-autonomous teams. They were given the freedom to take decisions and plan activities for their customers at small scale. In general, it came out from the survey that freedom within limits did not breed indiscipline but developed psychological ownership, which, in turn, enhanced job performance.

Third, sub-variable, which played a significant role in increasing job performance was experimentation. As most of the employees in the survey were front desk employees, therefore they said that almost daily they were experimenting with new ways for convincing customers to stay in their hotels. As they had direct dealing with customers therefore, every now and then they were to address customer's problems. Their openness for feedback and motivation for self-improvement helped them perform their job better.

\section{Discussion}

The study was carried out with the objectives of analyzing the effect of employee engagement variables and organizational culture variables that influenced the contextual and task performance of hotel employees. The primary results of this study revealed that there is a positive relationship between job performance and employee engagement and employee engagement had a greater impact on task performance as compared to contextual performance. This finding is supported by a recent longitudinal research study (Carter et al., 2018), which found a significant and positive correlation between employee engagement and job performance, and that employee engagement predicts job performance. Engaged employees have high in-role and extra-role performance, indicating that work engagement is positively related to job performance. The findings of the study are in line with the findings of Salanova et al. (2005), who conducted research on Spanish restaurants, stating that organizational resources and work engagement predicted service climate, which, in turn, predicted employee performance.

According to the "conservation of resources theory," which suggests that engaged employees are likely to put more effort into job performance, in terms of both in-role performance and extra-role performance; engaged employees were better job performers (Halbesleben, 2011; Macey et al., 2009). In the case of contextual performance, vigor had the maximum contribution, followed by absorption and dedication, whereas for task performance, the maximum contribution was that of absorption, followed by vigor. This implies that if the vigor and absorption of employees are improved, their job performance will increase. As stated by Kahn (1990), when people are engaged, they employ and express themselves psychologically, cognitively and emotionally during role performances.

Employees who felt most energetic and were most engrossed in their work and were most likely to show adequate task performance (Bakker et al., 2007). Thus, the energy, focus and sense of belongingness, which comes through employee engagement equip employees with higher potential and enhance their core abilities to face new situations and deal with new customers daily. Thus, the results of the first objective show that among the three subvariables of employee engagement taken for study - vigor, dedication and absorption affect contextual performance and vigor, as well as absorption, affect task performance, hotel employees. It also reveals that in the case of contextual performance vigor shows maximum contribution followed by absorption and dedication whereas for task performance maximum contribution is exhibited by absorption followed by vigor. 
The results of the study also show that organizational culture is a prerequisite that can influence organizational performance, and several steps need to be taken to enrich it. Among all the dimensions of organizational culture, the maximum contribution was that of experimentation, followed by autonomy and trust. Experimental culture is the independence that employees experience while expressing their ideas at work, the opportunities that they have for learning and innovative problem-solving. The organizational culture of risk-taking by employees is useful in improving their performance. The present findings support that of O'Reilly et al. (1991), that states that congruence between individual values and corporate values correlate significantly with individual productivity.

The next important dimension was found to be that of autonomy. The more autonomy an employee is given in decision-making, the more capable he/she feels of taking decisions, which is reflected in job performance. When individuals are given freedom for decisionmaking within a certain environment or work setting, they develop a sense of psychological ownership and self-possession, which helps improve their contextual and task performance. The current findings support that of Avey et al. (2009), which state that belongingness in terms of psychological ownership with an ability to take decisions in an organization improves job performance.

The third factor affecting job performance is trust. Trust in one's supervisor points to one's perception of faith and mutual independence in sharing one's thoughts. These findings are in line with the "relatedness needs" that every employee has toward his/her top management. Employees, who offer moral support and help employees and colleagues in crises and also rely on their seniors without fear of their misuse of trust, create an enriched organizational culture (Janssen et al., 1999). Thus, findings related to the second objective that was to explore the predictors of organizational culture influencing job performance of hotel employees identified - experimentation, autonomy and trust as major cultural predictors, which help to improve the contextual and task performance of employees.

\section{Conclusion}

This study aimed to examine the effects of employee engagement and organizational culture on the task and contextual performance of the employees in the hospitality industry. The indepth empirical analysis is done in the study, which revealed that employee engagement and organization culture influences the contextual and task performance of hotel employees. Employee engagement had a greater impact on task performance as compared to contextual performance and organizational culture can bring more change in the contextual performance of employees as compared to task performance.

Among employee engagement dimensions, vigor and absorption were found to be dominating factors. Energy, focus and involvement in one's work, which comes through employee engagement, enhanced the core capabilities of employees and enabled them to face new situations and daily challenges in the industry. Thus, looking at the importance of these factors regular feedback from employees needs to be maintained and addressed. An organizational culture of experimentation, autonomy and trust was found to improve the contextual and task performance of employees. The experimental culture of independence and risk-taking provides learning and innovative problem-solving opportunities to employees, which enhanced their performance. Psychological ownership, along with trust toward top management, helped to create an enriched work culture, which influenced both the contextual and task performance of employees. Therefore, a culture of trust and innovation should be encouraged among employees; the management should regularly interact with employees. 


\section{Limitations, implications and future research}

The present study was conducted to understand the role of organizational culture and employee engagement in contextual and task performance. The study has been conducted in hotels of Himachal Pradesh as they are one of the major contributors for gross domestic product of the state. The present study contributes to identify the factors that promote the job performance of hotel employees. As the hotel industry is fast spreading in the region, to meet the manpower needs of this industry, to augment their efficacy, to assess their job condition and ensure their welfare, this study must be undertaken regularly, year by year, with feedback to all the stakeholders of this industry. Our research has shown a positive relationship between employee engagement dimensions and job performance of employees.

Autonomy, participative culture, experimentation, autonomy and trust can improve the performance of the employees. Rewards and recognition can, proper track record of employees who left the organization can be kept and an informal exit interview can be helpful in enhancing employee engagement. Hospitality industry should work on building a culture based of trust, innovation, openness to enhance employee engagement and improve their performance. It is suggested that open hour sessions can be conducted where employees can suggest new initiatives or make other suggestions that may help increase the customer footfall in the hotel. In this session, employees could also discuss the problems confronted during the month, and the measures they took to overcome these or their expectations from the management regarding these challenges. This would help increase the commitment level of employees toward their organization and will improve organizational culture influencing job performance of hotel employees, and hence, chances of organizational success.

The current research acknowledges a few limitations in this study. First, the participants were hesitant to reveal about their current organizational profile such as their salary, age, their relations with their supervisors etc. Second, the problem of self-reporting biases, as it is a self-reported rating questionnaire needs to be taken into account. As the researcher was unable to record certain unexpressed problems of the employees, which might have proved useful in the research.

Further to strengthen this study, future research should also include the parameters of evaluation of demographics and organizational variables, which have an impact on employee engagement and the organizational culture of hotels in this hilly state of India. Future research can also be undertaken to compare the role of employees' engagement and organizational culture among managerial and non-managerial employees. A comparative study on employee engagement on government and private hotels can be undertaken in the future.

\section{References}

Avey, J.B., Avolio, B.J., Crossley, C.D. and Luthans, F. (2009), "Psychological ownership: theoretical extensions, measurement and relation to work outcomes", Journal of Organizational Behavior, Vol. 30 No. 2, pp. 173-191.

Bakker, A.B., Demerouti, E. and Lieke, L. (2012), "Work engagement, performance, and active learning: the role of conscientiousness", Journal of Vocational Behavior, Vol. 80 No. 2, pp. 555-564.

Bakker, A.B., Hakanen, J.J., Demerouti, E. and Xanthopoulou, D. (2007), "Job resources boost work engagement, particularly when job demands are high", Journal of Educational Psychology, Vol. 99 No. 2, pp. 274-284.

Baptiste, N.R. (2008), "Tightening the link between employee wellbeing at work and performance, a new dimension for HRM. Management Decision”, Management Decision, Vol. 46 No. 2, pp. 284-309. 
Behrman, D.N. and Perreault, W.D. (1982), "Measuring the performance of industrial salespersons", Journal of Business Research, Vol. 10 No. 3, pp. 355-370.

Bing, M.N. and Lounsbury, J.W. (2000), "Openness and job performance in US-based Japanese manufacturing companies", Journal of Business and Psychology, Vol. 14 No. 3, pp. 515-522.

Bommer, W.H., Johnson, J.L., Rich, G.A., Podsakoff, P.M. and MacKenzie, S.B. (1995), "On the interchangeability of objective and subjective measures of employee performance: A meta analysis", Personnel Psychology, Vol. 48 No. 3, pp. 587-605.

Borman, W.C. and Motowidlo, S.J. (1993), "Expanding the criterion domain to include elements of contextual performance", in Schmitt, N. and Borman, W.C. (Eds), Personnel selection in organizations, Jossey-Bass, San Francisco.

Borman, W.C., White, L.A. and Dorsey, D.W. (1995), "Effects of rate task performance and interpersonal factors on supervisor and peer performance ratings", Journal of Applied Psychology, Vol. 80, pp. 168-177.

Buil, I., Martínez, E. and Matute, J. (2019), "Transformational leadership and employee performance: the role of identification, engagement and proactive personality", International Journal of Hospitality Management, Vol. 77, pp. 64-75.

Carter, W.R., Nesbit, P.L., Badham, R.J., Parker, S.K. and Sung, L.-K. (2018), "The effects of employee engagement and self-efficacy on job performance: a longitudinal field study", The International Journal of Human Resource Management, Vol. 29 No. 17, pp. 2483-2502.

Carrell, M.R. and Elbert, N.F. (1974), "Some personal and organizational determinants of job the satisfaction of postal clerks", Academy of Management Journal, Vol. 17 No. 2, pp. 368-372.

Christen, M., Iyer, G. and Soberman, D. (2006), "Job satisfaction, job performance, and effort: a reexamination using agency theory" Journal of Marketing, Vol. 70 No. 1, pp. 137-150.

Conway, J.M. (1999), "Distinguishing contextual performance from task performance for managerial jobs", Journal of Applied Psychology, Vol. 84, pp. 3-13.

Chughtai, A.A. and Buckley, F. (2011), "Work engagement: antecedents, the mediating role of learning goal orientation and job performance", Career Development International, Vol. 16 No. 7, pp. 684-705.

De Romario, F., Dwija, I.G.A.M.A., Badera, I.D.N. and Putra, I.N.W.A. (2019), "Effect of budget participation towards regional government managerial performance", International Research Journal of Management, it and Social Sciences, Vol. 6 No. 3, pp. 101-107.

Department of tourism report (2019), No of hotels etc., available at: https:/himachaltourism.gov.in (accessed 27 June 2019).

Fauzi, M., Warso, M.M. and Haryono, A.T. (2016), "Pengaruh budaya organisasi dan kepuasan kerja terhadap kinerja karyawan dengan komitmen organisasi sebagai variabel intervening (studi pada karyawan PT. toys games Indonesia semarang)", Journal of Management, Vol. 2 No. 2, pp. 32-40.

Goffman E. (1961), Encounters: Two Studies in the Sociology of Interaction, Bobbs- Merrill co, Indianapolis.

Goodman, S.A. and Svyantek, D.J. (1999), "Person-organization fit and contextual performance: do shared values matter", Journal of Vocational Behavior, Vol. 55 No. 2, pp. 254- 275.

Greenberg, J. and Baron, R.A. (2003), Behavior in Organizations: Understanding and Managing the Human Side of Work, Prentice, Englewood Cliffs, NJ.

Gordon, G.G. and DiTomaso, N. (1992), "Predicting corporate performance from organizational culture”, Journal of Management Studies, Vol. 29, pp. 783-798.

Halbesleben, J.R. (2011), “The consequences of engagement: the good, the bad, and the ugly”, European Journal of Work and Organizational Psychology, Vol. 20 No. 1, pp. 68-73.

Halbesleben, J.R. and Wheeler, A.R. (2008), "The relative roles of engagement and embeddedness in predicting job performance and intention to leave”, Work \& Stress, Vol. 22 No. 3, pp. 242-256. 
Hartline, M.D. and Jones, K.C. (1996), "Employee performance cues in a hotel service environment: influence on perceived service quality, value, and word-of-mouth intentions", Journal of Business Research, Vol. 35 No. 3, pp. 207-215.

Hofhuis, J., van der Rijt, P.G.A. and Vlug, M. (2016), "Diversity climate enhances work outcomes through trust and openness in workgroup communication”, Springer Plus, Vol. 5, p. 714.

Hofstede, G. (1989), “Organizing for cultural diversity”, European Management Journal, Vol. 7 No. 4, pp. 389-96.

Hughes, J.C. and Rog, E. (2008), "Talent management: a strategy for improving employee recruitment, retention and engagement within hospitality organizations", International Journal of Contemporary Hospitality Management, Vol. 20 No. 7, pp. 743-757.

Ismail, H.N., Iqbal, A. and Nasr, L. (2019). "Employee engagement and job performance in Lebanon: the mediating role of creativity", International Journal of Productivity and Performance Management.

Janssen, P.P., De Jonge, J. and Bakker, A.B. (1999), "Specific determinants of intrinsic work motivation, burnout and turnover intentions: a study among nurses", Journal of advanced nursing, Vol. 29 No. 6, pp. 1360-1369.

Jena, L., Sajeet, P. and Nrusingh, P. (2018), "The pursuit of organisational trust: role of employee engagement, psychological well-being and transformational leadership", Asia Pacific Management Review.

Kahn, W.A. (1990), "Psychological conditions of personal engagement and disengagement at work", Academy of Management Journal, Vol. 33, pp. 692-724.

Kalia, N. and Bhardwaj, B.(2019), "Contextual and task performance: do demographic and organizational variables matter?”, Rajagiri Management Journal, Vol 13 No. 2, pp. 30-42.

Kim, T. and Chang, J. (2019), "Organizational culture and performance: a macro-level longitudinal study. Leadership \& Organization Development Journal.

Kónya, V., Matić, D. and Pavlović, J. (2016), "The influence of demographics, job characteristics and characteristics of organizations on employee commitment", Acta Polytechnica Hungarica, Vol. 13 No. 3, pp. 119-139.

Macey, W.H., Schneider, B., Barbera, K.M. and Young, S.A. (2009), Employee Engagement: Tools for Analysis, Practice, and Competitive Advantage, John Wiley \& Sons, New York.

Marcus, A. and Gopinath, N.M. (2017), "Impact of the demographic variables on the employee engagement - analysis. ICTACT", Journal on Management Studies, Vol. 03 No. 02, pp. 202-510.

Maroudas, L., Kyriakidou, O. and Vacharis, A. (2008), "Employees' motivation in the luxury hotel industry: the perceived effectiveness of human-resource practices”, Managing leisure, Vol. 13 No. 3, pp. 258-271.

Motowidlo, S.J. and Van Scotter, J.R. (1994), "Evidence that task performance should be distinguished from contextual performance", Journal of Applied psychology, Vol. 79 No. 4, pp. 475-480.

O'Reilly, C.A., Chatman, J. and Caldwell, D.F. (1991), "People and organizational culture: a profile comparison approach to assessing person-organization fit", Academy of Management Journal, Vol. 34 No. 3, pp. 487-516.

Pareek, U. (1994), Effective Organizations: Beyond Management to Institution Building, Oxford \& IBH, New Delhi.

Parker, S.K. and Griffin, M. (2011), "Understanding active psychological states: embedding engagement in a wider nomological net and closer attention to performance", European Journal of Work and Organizational Psychology, Vol. 20 No. 1, pp. 60-67.

Pettigrew, A.M. (1979), "On studying organizational cultures. Administrative Science Quarterly", Vol. 24, pp. $570-581$. 
Prasongthan, S. and Suveatwatanakul, C. (2017), "Employee engagement model: a study of Thai hotel industry", International Journal of Management and Applied Science, Vol.3 No. 3, pp. 17-22.

Pratiwi, N.J., Jamaluddin, J., Niswaty, R. and Salam, R.(2019), “The influence of work facilities on employee performance at the regional financial management agency secretariat section of south Sulawesi province", Jurnal Ad'ministrare, Vol. 6 No. 1, pp. 35-44.

Prihantari, G.A.P.E. and Astika, I.B.P. (2019), "Effect of role overload, budget participation, environmental uncertainty, organizational culture, competence, and compensation on employee performance", International research journal of management, IT and social sciences, Vol. 6 No. 4, pp. 197-206.

Rashid, Z.A., Sambasivan, M. and Johari, J. (2003), "The influence of corporate culture and organisational commitment on performance", Journal of Management Development.

Robbins, S.P. (2005), Organizational Behavior, Prentice Hall.

Sadiqe, M. (2014), "Employee engagement in hospitality industry in India: an overview", Global Journal of Finance and Management, Vol. 6 No. 4, pp. 375-378.

Salanova, M., Agut, S. and Peiró, J.M. (2005), "Linking organizational resources and work engagement to employee performance and customer loyalty: the mediation of service climate", Journal of Applied Psychology, Vol. 90 No. 6, pp. 12-17.

Schaufeli, W.B and Bakker, A.B. (2003) "Utrecht work engagement scale: preliminary manual," Occupational Health Psychology Unit, pp. 1-58.

Schaufeli, W.B., Salanova, M., González-Romá, V. and Bakker, A.B. (2002), "The measurement of engagement and burnout: a two sample confirmatory factor analytic approach", Journal of Happiness Studies, Vol. 3 No. 1, pp. 71-92.

Singh, A.K. (2010), "A study of HRM practices and organizational culture in selected private sector organizations in India”, Acta Oeconomica Pragensia, Vol. 4, pp. 64-80.

Subrahmanian, M.U. (2012), "Achieving high involvement and satisfaction through octapace culture in its companies", ZENITH International Journal of Business Economics \& Management Research, Vol. 2 No. 5, pp. 131-138.

Sukayana, G.A. and Putri, I.A.D. (2019), "Tri Hita Karana culture and organizational commitments moderate: effect of participation on budgetary slack", International research journal of management, IT and social sciences, Vol. 6 No. 4, pp. 180-188.

Tensay, A.T. and Singh, M. (2020), "The nexus between HRM, employee engagement and organizational performance of federal public service organizations in Ethiopia”, Heliyon, Vol. 6 No. 6, p. e04094.

Tourist Statistics (2021), Himachal tourism.gov.in Retrieved on June, 2020.

Widiani, N.P., Putri, A.M.A.D., Sari, M.M.R. and Wirajaya, I.G.A. (2019), "The effect of love of money and emotional intelligence on employee performance with organizational citizenship behavior as mediating variable", International Research Journal of Engineering, IT \& Scientific Research, Vol. 5 No. 1, pp. 39-49.

Zainol, S.S., Hussin, S.M. and Othman, M.S. (2016), "Determinants of employee engagement in hotel industry in Malaysia: a theoretical model", International Journal of Academic Research in Accounting, Finance and Management Sciences, Vol. 6 No. 3, pp. 1-9.

Zhang, H.Q. and Wu, E. (2004), "Human resources issues facing the hotel and travel industry in China", International Journal of Contemporary Hospitality Management, Vol. 16 No. 7, pp. 424-428.

\section{Further reading}

Economic survey of HP (2015), Economics and Statistics Department, Govt of Himachal Pradesh.

Lee, C., Law, K.S. and Bobko, P. (1999), "The importance of justice perceptions on pay effectiveness: a two-year study of a skill-based pay plan”, Journal of Management, Vol.25 No. 6, pp. 851-873. 
Lievens, F., Conway, J.M. and De Corte, W. (2008), "The relative importance of task, citizenship and counterproductive performance to job performance ratings: do rater source and team based culture matter?", Journal of Occupational and Organizational Psychology, Vol. 81 No. 1, pp. 11-27.

Singh, D. and Amandeep, A.D. (2017), "Impact of employee turnover on the hotel industry - a study of selected hotels of New Delhi”, International Journal of Research - Granthaalayah, Vol. 5, pp. 153-58.

World Travel and Tourism Council (2013), Travel and Tourism Economic Impact 2014, World, London.

Corresponding author

Bhawana Bhardwaj can be contacted at: bhawnabhardwaj113@gmail.com

For instructions on how to order reprints of this article, please visit our website: www.emeraldgrouppublishing.com/licensing/reprints.htm Or contact us for further details: permissions@emeraldinsight.com 